\title{
Trade Flow Dynamics with Heterogeneous Firms
}

\section{Citation}

Ghironi, Fabio, and Marc J. Melitz. 2007. Trade flow dynamics with heterogeneous firms. American Economic Review 97, no. 2: 356-361.

\section{Published Version}

http://dx.doi.org/10.1257/aer.97.2.356

\section{Permanent link}

http://nrs.harvard.edu/urn-3:HUL.InstRepos:3229097

\section{Terms of Use}

This article was downloaded from Harvard University's DASH repository, and is made available under the terms and conditions applicable to Other Posted Material, as set forth at http:// nrs.harvard.edu/urn-3:HUL.InstRepos:dash.current.terms-of-use\#LAA

\section{Share Your Story}

The Harvard community has made this article openly available.

Please share how this access benefits you. Submit a story.

Accessibility 


\title{
Trade Flow Dynamics with Heterogeneous Firms*
}

\author{
Fabio Ghironi ${ }^{\dagger}$ \\ Boston College, \\ $E A B C N$, and $N B E R$
}

\author{
Marc J. Melitz $z^{\ddagger}$ \\ Princeton University, \\ $C E P R$, and NBER
}

February 13, 2007

\begin{abstract}
We use a two-country, stochastic, general equilibrium model of international trade and macroeconomic dynamics with monopolistic competition and heterogeneous firms to explore the role of entry in the domestic economy and the extensive margin of international trade in the dynamics of U.S. trade flows over the business cycle. We show that the model can reproduce the evidence on the cyclicality of U.S. trade and important features of the evidence on the extensive margins of domestic entry and international trade. Entry in the domestic economy and the implied differences in the timing of export and import expansions in response to favorable productivity shocks provide the key mechanism for the model's ability to explain this range of stylized facts.

JEL Codes: F12; F41

Keywords: Business cycles; Entry; Exports; Imports; Trade balance; Variety
\end{abstract}

\footnotetext{
${ }^{*}$ We are grateful to Joachim Goeschel, Margarita Rubio, and Viktors Stebunovs for excellent research assistance. Remaining errors are our responsibility. We thank the NSF for financial support through a grant to the NBER.

${ }^{\dagger}$ Department of Economics, Boston College, 140 Commonwealth Avenue, Chestnut Hill, MA 02467-3859, U.S.A. or Fabio.Ghironi@bc.edu. URL: http://fmwww.bc.edu/ec/Ghironi.php.

${ }^{\ddagger}$ Department of Economics, Princeton University, Fisher Hall, NJ 08544, U.S.A.
} 


\section{Introduction}

Recent work, both theoretical and empirical, has highlighted a fundamental property of international trade patterns: when trade flows vary, either across countries or within a country over time, so does the number of goods embodied in those trade flows (as well as the number of firms engaging in those international transactions). This recent work has further shown that this extensive margin of trade plays a crucial role in explaining several important international economic phenomena. Before summarizing this work, we use the data from two of those studies, Broda, Greenfield, and Weinstein (2006) and Broda and Burstein (2006a), ${ }^{1}$ to graphically depict the relationship between the number of traded varieties and aggregate trade flows. We show this relationship for both exports (and exported varieties) and imports (and imported varieties) for a large sample of countries over the years 1994-2003 in Figures 1 and 2. ${ }^{2}$ The left-hand side panel portrays the full panel relationship between varieties and trade (both expressed in logs), while the right-hand side panel focuses on the within-country growth variation: for each country, the year to year growth rate (log difference) is expressed as a deviation from the country-level mean growth rate (and thus is purged of any country-level secular growth trend). ${ }^{3}$ The figures overwhelmingly document the important comovement between trade flows and the extensive margin of trade, both across countries and within countries over time. Eaton, Kortum, and Kramarz (1994) have also documented this important extensive margin component of trade flows for bilateral trade flows for France, measuring the extensive margin as the number of French firms exporting to a particular destination.

This extensive margin component of trade is not an inconsequential property of trade flows that can safely be ignored. Its recent explicit incorporation into general equilibrium trade models has radically affected many aspects of the literature. Kehoe and Ruhl (2002) show how large responses of trade flows to small but long-lasting reductions in trade costs (driven by trade liberalization) are driven by a substantial response in the extensive margin of trade (export of new goods). Ruhl (2003) theoretically shows how such differences in the extensive margin of trade responses - between transitory business cycle and long lasting trade liberalization shocks - can explain the observed very large differences in the elasticity of trade response at high versus low frequencies. Helpman, Melitz, and Rubinstein (2006) show how the incorporation of the extensive margin of trade can substantially

\footnotetext{
${ }^{1}$ We are immensely grateful to Christian Broda for graciously sharing this data.

${ }^{2} \mathrm{~A}$ variety is defined as positive trade for a 6-digit Harmonized System (HS) product category.

${ }^{3}$ The left-hand side panel for exports clearly illustrates that the number of exported varieties is censored at a maximum level for the largest exporters.
} 
improve the fit and predictive power of the standard bilateral trade gravity specifications. ${ }^{4}$ Chaney (2006) shows both theoretically and empirically how the extensive margin of trade reverses the (previously assumed) amplification effect of product substitutability on trade costs. Broda and Weinstein (2006a) and Broda et al (2006) focus on the extensive margin for imports. They quantify the gains for the U.S. of the secular growth in its extensive margin of imports, resulting in additional product variety for U.S. consumers. This extensive margin is not accounted for in U.S. price indices (either for imports or the CPI more generally) and entails substantial previously unmeasured welfare gains for U.S. consumers. In Broda et al (2006), the authors show that, across a wide sample of countries, the growth in the extensive margin of imports can also account for an important component of that country's productivity growth (this effect is amplified for developing countries). Atkeson and Burstein (2006) show how the modeling of the extensive margin of trade, along with firm heterogeneity and oligopolistic pricing can best explain the strong evidence on pricing to market for the U.S.

In this paper, we document how the model developed in Ghironi and Melitz (2005) explicitly incorporates these key extensive margin empirical features into an international real business cycle model that further replicates many other important empirical features of net and gross trade flows over the cycle. The endogenous response of the extensive margin of trade is driven by two crucial new features in our model: First and foremost, our model endogenizes the development and introduction of new varieties over the business cycle - subject to sunk costs. Second, however, not all introduced varieties are traded: the firms that produce these varieties face fixed export costs (as well as per-unit trade costs) and only export a variety when it is profitable to do so. Thus, the extensive margin of trade at any given time is jointly determined by the endogenous total number of varieties introduced in the economy, along with the endogenous subset of those varieties that are exported. Both channels fluctuate over the business cycle as the economy and its trading partner experience a series of productivity shocks.

Recent empirical evidence for the U.S. has also substantiated the endogenous fluctuations in available domestic varieties at the heart of our model. A previous literature had previously documented the strong pro-cyclical behavior of net producer entry (measured either as incorporated firms or as production establishments). ${ }^{5}$ Bernard, Redding, and Schott (2006) further document how existing establishments devote a substantial portion of their production to goods that they

\footnotetext{
${ }^{4}$ Eaton and Kortum (2002) provide a very important precedent which first incorporates the extensive margin into a multi-country trade model that delivers a gravity specification for bilateral trade.

${ }^{5}$ See Campbell (1998), Devereux, Head, and Lapham (1996a, 1996b), and Chatterjee and Cooper (1993).
} 
did not previously produce. Broda and Weinstein (2006b) and Axarloglou (2003) directly measure the introduction of new varieties in the U.S. economy and document a strong correlation with the business cycle: disproportionately more new varieties are introduced during U.S. expansions. Our model replicates these important patterns of pro-cyclical entry for goods and producers. ${ }^{6}$ Forward looking, monopolistically competitive producers make endogenous product entry decisions subject to sunk development costs. In our general equilibrium framework, these are captured by real resources which must be expended to cover these costs (and thus represent resources that are then unavailable for use in goods production). These sunk costs introduce substantial endogenous persistence to several key macroeconomic variables in our model - most directly, via the sluggish response of the available number of products in the economy. We document this sluggish response of the number of establishments in the U.S. and show how our model captures the key features of its comovements with GDP.

The endogenous export decision for each good produced then generates a second channel that affects the extensive margin of trade. Goods are produced with heterogeneous technologies, leading to differences in productivity (which can also be thought of as product quality differences). This implies that only a subset of relatively more productive goods are exported. This proportion of exported goods then also fluctuates with the business cycle. These features match up well with the empirical firm-level evidence on productivity, export status, and export market entry and exit (see Ghironi and Melitz (2005) for further details). Furthermore, our model captures the key aggregate business cycle comovements between the number of traded varieties and the aggregate trade levels.

We embed these macroeconomic features into a two-country dynamic, stochastic, general equilibrium (DSGE) model of international real business cycles. Prices are fully flexible, and we allow for international trade in bonds (which provide a risk-free real rate of return). This allows us to investigate the dynamic responses of both net and gross trade flows. Again, we document how our model captures very well the key cross-correlations of these variables with domestic GDP over the business cycle.

The rest of the paper is organized as follows. Section 2 describes our model. Section 3 presents the model's implications for the cyclicality of trade flows and domestic and traded product variety in relation to U.S. data. Section 4 concludes.

\footnotetext{
${ }^{6}$ Our model does not address the distinction between firms, establishments, and products. The key unit of production in our model is a production line for a particular good. We do not model how these production lines are distributed across establishments and firms. When we refer to a producer or firm, we have in mind the production line for an individual good.
} 


\section{The Model}

We now briefly describe the main features of our model, which is developed in much more detail in Ghironi and Melitz (2005).

\section{Household Preferences and Intratemporal Choices}

The world consists of two countries, home and foreign. We denote foreign variables with a superscript star. Each country is populated by a unit mass of atomistic households. All contracts and prices in the world economy are written in nominal terms. Prices are flexible and money is used only as unit of account.

The representative home household supplies $L$ units of labor inelastically in each period at the nominal wage rate $W_{t}$, denominated in units of home currency. The household maximizes expected intertemporal utility from consumption $(C): E_{t}\left[\sum_{s=t}^{\infty} \beta^{s-t} C_{s}^{1-\gamma} /(1-\gamma)\right]$, where $\beta \in(0,1)$ is the subjective discount factor and $\gamma>0$ is the inverse of the intertemporal elasticity of substitution. At time $t$, the household consumes the basket of goods $C_{t}$, defined over a continuum of goods $\Omega$ : $C_{t}=\left(\int_{\omega \in \Omega} c_{t}(\omega)^{\theta-1 / \theta} d \omega\right)^{\theta /(\theta-1)}$, where $\theta>1$ is the symmetric elasticity of substitution across goods. At any given time $t$, only a subset of goods $\Omega_{t} \subset \Omega$ is available. Let $p_{t}(\omega)$ denote the home currency price of a good $\omega \in \Omega_{t}$. The consumption-based price index for the home economy is then $P_{t}=\left(\int_{\omega \in \Omega_{t}} p_{t}(\omega)^{1-\theta} d \omega\right)^{1 /(1-\theta)}$, and the household's demand for each individual good $\omega$ is $c_{t}(\omega)=\left(p_{t}(\omega) / P_{t}\right)^{-\theta} C_{t}$.

The foreign household supplies $L^{*}$ units of labor inelastically in each period in the foreign labor market at the nominal wage rate $W_{t}^{*}$, denominated in units of foreign currency. It maximizes a similar utility function, with identical parameters and a similarly defined consumption basket. Crucially, the subset of goods available for consumption in the foreign economy during period $t$ is $\Omega_{t}^{*} \subset \Omega$ and can differ from the subset of goods that are available in the home economy.

\section{Production, Pricing, and the Export Decision}

There is a continuum of firms in each country, each producing a different variety $\omega \in \Omega$. Production requires only one factor, labor. Aggregate labor productivity is indexed by $Z_{t}\left(Z_{t}^{*}\right)$, which represents the effectiveness of one unit of home (foreign) labor. Firms are heterogeneous as they produce with different technologies indexed by relative productivity $z$. A home (foreign) firm with relative productivity $z$ produces $Z_{t} z\left(Z_{t}^{*} z\right)$ units of output per unit of labor employed. All firms face a 
residual demand curve with constant elasticity $\theta$ in both markets, and they set prices that reflect the same proportional markup $\theta /(\theta-1)$ over marginal cost.

Prior to entry, firms are identical and face a sunk entry cost of $f_{E, t}\left(f_{E, t}^{*}\right)$ effective labor units, equal to $w_{t} f_{E, t} / Z_{t}\left(w_{t}^{*} f_{E, t}^{*} / Z_{t}^{*}\right)$ units of the home (foreign) consumption good, where $w_{t} \equiv W_{t} / P_{t}$ $\left(w_{t}^{*} \equiv W_{t}^{*} / P_{t}^{*}\right)$ represents the real wage of home (foreign) workers. Upon entry, home firms draw their productivity level $z$ from a common Pareto distribution $G(z)$ with lower bound $z_{\text {min }}$ and shape parameter $k>\theta-1: G(z) \equiv 1-\left(z_{\min } / z\right)^{k} \cdot{ }^{7}$ Foreign firms draw their productivity level from an identical distribution. This relative productivity level remains fixed thereafter. Since there are no fixed production costs, all firms produce in every period, until they are hit with a "death" shock, which occurs with probability $\delta \in(0,1)$ in every period. This exit inducing shock is independent of the firm's productivity level, so $G(z)$ also represents the productivity distribution of all producing firms.

Home and foreign firms can serve both their domestic market as well as the export market. Exporting is costly, and involves both a melting-iceberg trade cost $\tau_{t} \geq 1\left(\tau_{t}^{*} \geq 1\right)$ as well as a fixed cost $f_{X, t}\left(f_{X, t}^{*}\right)$ (measured in units of effective labor) in every period. Due to the fixed export cost, firms with low productivity levels $z$ may decide not to export in any given period. When making this decision, a firm decomposes its total profit $d_{t}(z)\left(d_{t}^{*}(z)\right)$ (returned to households as dividends) into portions earned from domestic sales $d_{D, t}(z)\left(d_{D, t}^{*}(z)\right)$ and from potential export sales $d_{X, t}(z)$ $\left(d_{X, t}^{*}(z)\right)$, net of the fixed export cost. All these profit levels (dividends) are expressed in real terms in units of the consumption basket in the firm's location. In the case of a home firm, total profits in period $t$ are given by $d_{t}(z)=d_{D, t}(z)+d_{X, t}(z)$. As expected, more productive firms earn higher profits (relative to less productive firms), although they set lower prices. A firm will export if and only if it would earn non-negative profit from doing so. For home firms, this will be the case so long as productivity $z$ is above a cutoff level $z_{X, t}=\inf \left\{z: d_{X, t}(z)>0\right\}$. A similar cutoff level $z_{X, t}^{*}=\inf \left\{z: d_{X, t}^{*}(z)>0\right\}$ holds for foreign exporters. We assume that the lower bound productivity $z_{\min }$ is low enough relative to the export costs that $z_{X, t}$ and $z_{X, t}^{*}$ are both above $z_{\min }$. This ensures the existence of an endogenously determined non-traded sector: the set of firms who could export, but decide not to. These firms, with productivity levels between $z_{\text {min }}$ and the export cutoff level, only produce for their domestic market. This set of firms fluctuates over time with changes in the profitability of the export market, inducing changes in the cutoff levels $z_{X, t}$ and $z_{X, t}^{*}$.

\footnotetext{
${ }^{7}$ This implies that firm size is also distributed Pareto, which fits the corresponding empirical distribution quite well.
} 
In every period, a mass $N_{D, t}\left(N_{D, t}^{*}\right)$ of firms produces in the home (foreign) country. These firms have a distribution of productivity levels over $\left[z_{\min }, \infty\right)$ given by $G(z)$. Among these firms, there are $N_{X, t}=\left[1-G\left(z_{X, t}\right)\right] N_{D, t}$ and $N_{X, t}^{*}=\left[1-G\left(z_{X, t}^{*}\right)\right] N_{D, t}^{*}$ exporters.

\section{Firm Entry and Exit}

In every period, there is an unbounded mass of prospective entrants in both countries. These entrants are forward looking, and correctly anticipate their future expected profits $\tilde{d}_{t}\left(\tilde{d}_{t}^{*}\right)$ in every period as well as the probability $\delta$ (in every period) of incurring the exit-inducing shock. The preentry expected profit is equal to post-entry average profit, hence $\tilde{d}_{t}=\int_{z_{\min }}^{\infty} d_{t}(z) d G(z){ }^{8}$ We assume that entrants at time $t$ only start producing at time $t+1$, which introduces a one-period time-tobuild lag in the model. The exogenous exit shock occurs at the very end of the time period (after production and entry). A proportion $\delta$ of new entrants will therefore never produce. Prospective home entrants in period $t$ compute their expected post-entry value given by the present discounted value of their expected stream of profits $\left\{\tilde{d}_{s}\right\}_{s=t+1}^{\infty}$ :

$$
\tilde{v}_{t}=E_{t} \sum_{s=t+1}^{\infty}[\beta(1-\delta)]^{s-t}\left(\frac{C_{s}}{C_{t}}\right)^{-\gamma} \tilde{d}_{s} .
$$

This also represents the average value of incumbent firms after production has occurred (since both new entrants and incumbents then face the same probability $1-\delta$ of survival and production in the subsequent period). Firms discount future profits using the household's stochastic discount factor, adjusted for the probability of firm survival $1-\delta$. Entry occurs until the average firm value is equalized with the entry cost, leading to the free entry condition $\tilde{v}_{t}=w_{t} f_{E, t} / Z_{t}$. This condition holds so long as the mass $N_{E, t}$ of entrants is positive. We assume that macroeconomic shocks are small enough for this condition to hold in every period. Finally, the timing of entry and production we have assumed implies that the number of home producing firms during period $t$ is given by $N_{D, t}=(1-\delta)\left(N_{D, t-1}+N_{E, t-1}\right)$. Similar free entry condition, requirement on the size of shocks, and law of motion for the number of producing firms hold in the foreign country.

\section{Household Budget Constraint and Intertemporal Choices}

Households in each country hold two types of assets: shares in a mutual fund of domestic firms and domestic and foreign bonds. Home bonds, issued by home households, are denominated in

\footnotetext{
${ }^{8}$ Throughout, we use tildes $(\sim)$ to represent averages across firms.
} 
home currency. Foreign bonds, issued by foreign households, are denominated in foreign currency. Nominal returns are indexed to inflation in each country, so that bonds issued by each country provide a risk-free, real return in units of that country's consumption basket. International asset markets are incomplete, as only risk-free bonds are traded across countries. Standard quadratic costs of adjusting bond holdings ensure determinacy of the steady state and stationarity in response to transitory shocks. ${ }^{9}$ The costs are paid to competitive intermediaries that rebate them to households in equilibrium, and they are parametrized to have a small impact on model dynamics, other than ensuring stationarity in the long run.

Focus on the home economy. Let $x_{t}$ be the share in the mutual fund of home firms held by the representative home household entering period $t$. The mutual fund pays a total profit in each period (in units of home currency) that is equal to the average total profit of all home firms that produce in that period, $P_{t} \tilde{d}_{t} N_{D, t}$. During period $t$, the representative home household buys $x_{t+1}$ shares in a mutual fund of $N_{H, t} \equiv N_{D, t}+N_{E, t}$ home firms (those already operating at time $t$ and the new entrants). Only $N_{D, t+1}=(1-\delta) N_{H, t}$ firms will produce and pay dividends at time $t+1$. Since the household does not know which firms will be hit by the exogenous exit shock $\delta$ at the very end of period $t$, it finances the continuing operation of all pre-existing home firms and all new entrants during period $t$. The date $t$ price (in units of home currency) of a claim to the future profit stream of the mutual fund of $N_{H, t}$ firms is equal to the average nominal price of claims to future profits of home firms, $P_{t} \tilde{v}_{t}$.

The budget constraint of the representative home household, in units of the home consumption basket, is:

$$
\begin{aligned}
B_{t+1}+Q_{t} B_{*, t+1}+\frac{\eta}{2}\left(B_{t+1}\right)^{2}+ & \frac{\eta}{2} Q_{t}\left(B_{*, t+1}\right)^{2}+\tilde{v}_{t} N_{H, t} x_{t+1}+C_{t} \\
& =\left(1+r_{t}\right) B_{t}+Q_{t}\left(1+r_{t}^{*}\right) B_{*, t}+\left(\tilde{d}_{t}+\tilde{v}_{t}\right) N_{D, t} x_{t}+T_{t}^{f}+w_{t} L
\end{aligned}
$$

where $Q_{t} \equiv \varepsilon_{t} P_{t}^{*} / P_{t}$ is the consumption-based real exchange rate (units of home consumption per unit of foreign consumption; $\varepsilon_{t}$ is the nominal exchange rate, units of home currency per unit of foreign), $r_{t}$ and $r_{t}^{*}$ are the consumption-based interest rates on holdings of domestic and foreign bonds between $t-1$ and $t$ (known with certainty as of $t-1$ ), $B_{t+1}$ denotes holdings of home bonds, $B_{*, t+1}$ denotes holdings of foreign bonds, $(\eta / 2)\left(B_{t+1}\right)^{2}$ is the cost of adjusting holdings of home bonds, $(\eta / 2)\left(B_{*, t+1}\right)^{2}$ is the cost of adjusting holdings of foreign bonds (in units

\footnotetext{
${ }^{9}$ See Ghironi (2006) and Schmitt-Grohé and Uribe (2003) for more details.
} 
of foreign consumption), $T_{t}^{f}$ is the fee rebate, taken as given by the household, and equal to $(\eta / 2)\left[\left(B_{t+1}\right)^{2}+Q_{t}\left(B_{*, t+1}\right)^{2}\right]$ in equilibrium. For simplicity, we assume that the scale parameter $\eta>0$ is identical across costs of adjusting holdings of home and foreign bonds. Also, there is no cost of adjusting equity holdings to avoid adding unnecessary complication.

Utility maximization yields Euler equations for bond and equity holdings. The fees for adjusting bond holdings imply that the Euler equations for bond holdings feature a term that depends on the stock of bonds - delivering determinacy of the steady state and model stationarity. Euler equations for bond holdings in each country imply a no-arbitrage condition between bonds. When the model is log-linearized around the steady state, this no-arbitrage condition relates (in a standard fashion) the real interest rate differential across countries to expected depreciation of the consumptionbased real exchange rate. Forward iteration of the Euler equation for share holdings and absence of speculative bubbles yield the asset price solution in equation (1). ${ }^{10}$

The change in equilibrium asset holdings between $t$ and $t+1$ is a country's current account. Home and foreign current accounts add to zero when expressed in units of the same consumption basket. In what follows, GDP is defined as total labor and dividend income, $y_{t} \equiv w_{t} L+N_{D, t} \tilde{d}_{t}$, total exports in units of home consumption are $X_{t} \equiv Q_{t}\left(C_{t}^{*}-N_{D, t}^{*} \theta \tilde{d}_{D, t}^{*}\right)$, and total imports in units of home consumption are $I M_{t} \equiv C_{t}-N_{D, t} \theta \tilde{d}_{D, t}{ }^{11}$ The trade balance is $T B_{t} \equiv X_{t}-I M_{t}$.

\section{International Trade and Variety over the Business Cycle}

We solve the model by log-linearization around the unique, symmetric steady state with zero bond holdings implied by the assumptions of constant, equal aggregate productivities $\left(Z_{t}=Z_{t}^{*}=Z=1\right)$ and entry and trade costs $\left(f_{E, t}=f_{E, t}^{*}=f_{E}, f_{X, t}=f_{X, t}^{*}=f_{X}, \tau_{t}=\tau_{t}^{*}=\tau\right)$. We assume that entry and trade costs remain constant at their steady-state values in the exercise below and posit a bivariate $A R(1)$ process for the percent deviations of home and foreign productivities from the steady state that are the source of business cycles.

\footnotetext{
${ }^{10}$ Transversality conditions for bonds and shares must also be satisfied to ensure optimality. The foreign household maximizes its utility function subject to a similar budget constraint, resulting in analogous Euler equations and transversality conditions.

${ }^{11}$ Aggregate consumption (in units of the home consumption basket) of home produced goods by home consumers is $N_{D, t} \theta \tilde{d}_{D, t}$.
} 


\section{Calibration}

We interpret periods as quarters and set $\beta=.99$ and $\gamma=2-$ both standard choices for quarterly business cycle models. We set the scale parameter for the bond adjustment cost to .0025 - sufficient to generate stationarity in response to transitory shocks but small enough to avoid overstating the role of this friction in determining the dynamics of our model. We set the size of the exogenous firm exit shock $\delta=.025$ to match the U.S. empirical level of 10 percent job destruction per year. We use the value of $\theta$ from Bernard, Eaton, Jensen, and Kortum (2003) and set $\theta=3.8$ to fit U.S. plant and macro trade data, and we set $k=3.4$, satisfying the requirement $k>\theta-1$. We postulate $\tau=1.3$, roughly in line with Obstfeld and Rogoff (2001), and set the steady-state fixed export cost $f_{X}$ such that the proportion of exporting plants matches the number reported in Bernard et al (2003) - 21 percent. This leads to a fixed export cost $f_{X}$ equal to 23.5 percent of the per-period, amortized flow value of the entry cost, $[1-\beta(1-\delta)] /[\beta(1-\delta)] f_{E}$. Changing the entry cost $f_{E}$ while maintaining the same ratio $f_{X} / f_{E}$ does not affect impulse responses. We therefore set $f_{E}$ to 1 without loss of generality. For similar reasons, we normalize $z_{\min }$ to 1 . Our calibration implies that exporters are on average 58.2 percent more productive than non-exporters. The steady-state share of expenditure on domestic goods is .733 , and the share of expenditure on non-traded domestic goods is .176. The relative size differential of exporters relative to non-exporters in the domestic market is $3.61 .^{12}$

We set the variance-covariance matrix of innovations in the bivariate productivity process to the values estimated by Backus, Kehoe, and Kydland (1992) and used in much subsequent literature: .73 percent variance and .258 correlation (or .19 percent covariance). However, we follow the evidence in Baxter (1995) and Baxter and Farr (2005) in assuming that the $A R(1)$ coefficient matrix features near unit root persistence (.999) and no spillover. ${ }^{13}$

\section{Correlations}

Figure 3 presents evidence on the cyclical properties of U.S. trade - the correlations between U.S. GDP and the trade balance (as a ratio to GDP), exports, and imports at various leads and lags and the counterparts to these moments generated by our model. ${ }^{14}$ The figure shows an S-shaped

\footnotetext{
${ }^{12}$ More details on the calibration are in Ghironi and Melitz (2005).

${ }^{13}$ We experimented using the $A R(1)$ coefficient matrix of Backus, Kehoe, and Kydland (1992) - with persistence .906 and spillover parameter .088 - and the matrix in Kehoe and Perri (2002) - with persistence .95 and no spillover. Key qualitative results were unaffected.

${ }^{14}$ The figure also shows the 95 percent confidence bands around the data correlations. These are based on logged, HP-filtered quarterly data, 1957:1-2006:2, with HP filter parameter $\lambda=1,600$, except for the trade-balance-to-
} 
pattern for the correlation between U.S. GDP and the trade balance (as a ratio to GDP) at various leads and lags. The trade balance is countercyclical (the contemporaneous correlation is negative) as documented by Backus, Kehoe, and Kydland $(1992,1994)$. However, the correlation between current GDP and future trade balances becomes positive. The correlations of gross trade flows with GDP explain this time profile of the cyclicality of net trade. While the correlation of exports with GDP displays an S-shaped profile, with the peak positive correlation happening several periods in the future, the correlation of imports with GDP is roughly tent-shaped, with the positive peak happening much earlier. This results in the contemporaneous countercyclicality of net trade and its expansion relative to GDP in the future.

Our model captures these qualitative patterns remarkably well. The intuition for the countercyclicality of the trade balance is analogous to that in the international real business cycle models of Backus, Kehoe, and Kydland $(1992,1994)$ and other studies. As we emphasized in Ghironi and Melitz (2005), creation of new production lines associated to new varieties is a form of capital accumulation in our model, financed through the saving decisions of households. A new production line (identified with a firm in our model) is a unit of capital that is then combined with labor to produce output in all following periods, until hit by the exogenous exit shock. When a favorable shock induces the economy to expand, agents borrow from abroad to finance faster entry of new production lines in the more attractive business environment, resulting in a countercyclical trade balance. While imports increase quickly as consumer demand expands, export expansion is slower, as the gradual increase in the number of home producers results in a gradual increase in the number of exporters. ${ }^{15}$

Entry of new production lines associated with product creation and the dynamics of the extensive margin of trade are central for the ability of our model to reproduce the cyclical behavior of U.S. trade. We reviewed some evidence on the significance of product creation and the extensive margin of trade over the business cycle in the Introduction. ${ }^{16}$ Figure 4 shows that our model comes also quite close to matching the evidence on the cyclical variation in the number of establishments in

GDP ratio, which is not logged. Nominal values and the GDP deflator are from the International Monetary Fund's International Financial Statistics. Model-based correlations are computed with the frequency domain technique described in Uhlig (1999), applying the HP filter to remove low-frequency fluctuations that are not picked up by HPfiltered data. Data-consistent real variables in our model are obtained by deflating nominal variables by an average price index that removes the pure variety effect implicit in welfare-consistent price indexes. For any variable $x_{t}$ in units of consumption, the data-consistent counterpart is $x_{R, t} \equiv P_{t} x_{t} / \tilde{P}_{t}$, where $\tilde{P}_{t} \equiv P_{t} N_{t}^{1 /(\theta-1)}$ and $N_{t} \equiv N_{D, t}+N_{X, t}^{*}$ is the total number of varieties sold at home.

${ }^{15}$ As the discussion of impulse responses below substantiates, it is expansion along the extensive export margin that increases total home exports in our model, with lower output per exporter.

${ }^{16}$ See also Bilbiie, Ghironi, and Melitz (2005) for more discussion of evidence on entry and product creation over the business cycle, and its role as capital accumulation. 
U.S. manufacturing. ${ }^{17}$ The correlation function displays negative correlation between the number of establishments sufficiently in the past and current GDP, positive contemporaneous correlation, and positive correlation between current GDP and the number of establishments in the future. A higher GDP is associated with a relatively larger number of establishments that operate currently and in the future, as economic expansion stimulates business creation. The negative correlation between current GDP and the number of establishments sufficiently in the past is equivalent to a negative correlation between the current number of establishments and GDP several quarters ahead, consistent with expansion in product variety taking place before GDP has reached the peak of a cycle. The S-shaped pattern generated by our model - in which entry takes place in anticipation of economic expansion - is not distant from the empirical correlation.

Figure 4 also illustrates the properties of our model in relation to data with respect to the extensive margin of international trade by presenting correlations between real exports (imports) and the number of exported (imported) varieties at various leads and lags. ${ }^{18}$ Consistent with the data, the model predicts a tent-shaped correlation between exports and the number of exported varieties. The correlation is too strong relative to the data, but we conjecture that this is a consequence of abstracting from sunk export market entry costs in the model. The model also predicts a tent-shaped correlation between imports and the number of imported varieties, with essentially perfect contemporaneous correlation. This is the predicted moment that is most different from the available U.S. data, although the prediction of a strong correlation is qualitatively consistent with the cross-country evidence we presented above. Unfortunately, the available series on exported and imported varieties for the U.S. are much shorter than the other data series in our exercise, making it hard to identify clear, statistically significant patterns, particularly on the import side. For this reason - and given the strong cross-country evidence - we do not view the inability of the model to replicate the absence of a significant contemporaneous correlation between imports and imported varieties suggested by this limited U.S. data as a major setback. ${ }^{19}$ Overall, the model does remarkably well at replicating several features of evidence on the cyclicality of U.S. trade

\footnotetext{
${ }^{17}$ The quarterly series of the number of establishments, 1975:1-2000:4, is from the Quarterly Census of Employment and Wages. The series is logged and HP-filtered before computing the correlation in Figure 4.

${ }^{18}$ The data on exported and imported varieties are the numbers of exported and imported HTS codes reported by the U.S. in Feenstra, Romalis, and Schott (2002), 1989-2001, and are available from the NBER's web site. The average number of exported (imported) varieties is 7,201 (14,064). We obtained quarterly series by linear interpolation of the annual data.

${ }^{19}$ It should also be noted that the correlation between import value and imported varieties at yearly frequency displays a tent shape, with statistically significant and positive contemporaneous correlation, between leads and lags of GDP from -2 to 2 . The yearly frequency also increases the peak correlation between export value and exported varieties.
} 
and changes along domestic and international extensive margins under a calibration that was not chosen to match any of these features. ${ }^{20}$

\section{Impulse Responses}

To further substantiate the intuitions above, Figure 5 presents impulse responses to a 1 percent increase in home productivity, with persistence .999 and no spillover. The number of years after the shock is on the horizontal axis and the percent deviation from steady state is on the vertical axis (normalized so that 1 denotes 1 percent). The first row shows the responses of aggregate trade flows and home and foreign GDP, in data-consistent units. Home runs a trade deficit, owing to an initial decline in exports and an upward spike in imports as consumer demand booms and the economy borrows to finance entry of new firms in the more productive environment. Entry puts pressure on the cost of home effective labor relative to foreign, measured by the "terms of labor", $T O L_{t} \equiv \varepsilon_{t}\left(W_{t}^{*} / Z_{t}^{*}\right) /\left(W_{t} / Z_{t}\right){ }^{21}$ The terms of labor appreciate on impact, resulting in a short-run drop in the number of home exporters. ${ }^{22}$ In the short run, home exports fall because of both a decrease in the number of exporters and a drop in exports of each individual exported good $\left(X_{t}(z)\right)$ - the latter due to the higher price $\left(\rho_{X, t}(z) \equiv p_{X, t}(z) / P_{t}^{*}\right)$ induced by higher labor costs. Over time, as the number of home producing firms increases, the number of exporters rebounds before settling on the trajectory back to the initial steady state from above. A depreciation of the terms of labor relative to the initial appreciation contributes to this rebound in the number of home exporters: As home consumption expands further and firm entry into home cools down after the initial spike, the demand of foreign goods for consumption shifts pressure on the cost of foreign effective labor. In turn, this temporarily lowers the cutoff for home export productivity relative to the initial increase. As the number of producing home firms continues to increase,

\footnotetext{
${ }^{20}$ We focus on trade flows and the cyclicality of product introduction and traded variety in this paper. Our model has also implications for international relative prices, which we addressed in detail in Ghironi and Melitz (2005). With regard to the cyclicality of the terms of trade, the model does not replicate the S-curve correlation with the trade balance documented in Backus, Kehoe, and Kydland (1994) if one uses the relative price of any pair of home and foreign goods that do not change traded status in response to a shock as measure of the terms of trade. The reason is that this measure of the terms of trade improves in response to favorable productivity shocks due to the effect of entry on the relative cost of effective labor across countries. This is consistent with evidence in Corsetti, Dedola, and Leduc (2004) and Debaere and Lee (2004), but not with the terms of trade response to a shock in Backus, Kehoe, and Kydland's model. Our model can generate the S-curve, with the terms of trade worsening contemporaneously to a trade deficit, if one uses the average terms of trade that takes into account the extensive margin of trade by factoring in the changes in export productivity cutoffs at home and abroad.

${ }^{21}$ This is related to the double factorial terms of trade. The two concepts are distinct because our measure adjusts for the productivity of all labor, not just the productivity in the export and import sectors (which are endogenous in our model).

${ }^{22}$ The export productivity cutoff, $z_{X, t}$, increases because fixed trade costs require firms to hire relatively more expensive labor.
} 
the less productive home exporters start dropping out of the export market due to resumed labor appreciation, but the number of home exporters remains above the steady state for a very long time. It is this expansion in exported varieties (with output of each exported variety remaining below the steady state) that induces total home exports to rise quickly above the steady state (so that the trade balance, not as a ratio to GDP, rises above the steady state about three years after the shock to ensure that the country's intertemporal budget constraint is satisfied). The different timings of import and export expansion, and the roles of changing domestic and traded variety explain the model correlation patterns illustrated in Figures 3 and 4.

\section{Conclusions}

We used a two-country, stochastic, general equilibrium model of international trade and macroeconomic dynamics with monopolistic competition and heterogeneous firms to explore the role of entry in the domestic economy and the extensive margin of international trade in the dynamics of U.S. trade flows over the business cycle. There is substantial evidence of the association of producer entry, product introduction, and economic fluctuations in the U.S., and strong evidence of the connection between trade flows and changes in the range of traded varieties across countries. We showed that our model can reproduce the evidence on the cyclicality of U.S. trade and important features of the evidence on the extensive margins of domestic entry and international trade. Entry in the domestic economy and the implied differences in the timing of export and import expansions in response to favorable shocks provide the key mechanism for the model's ability to explain this range of stylized facts.

\section{References}

[1] Atkeson, A., and A. Burstein (2006): "Pricing-to-Market, Trade Costs, and International Relative Prices," mimeo, UCLA.

[2] Axarloglou, K. (2003): "The Cyclicality of New Product Introductions," Journal of Business 76: $29-48$.

[3] Backus, D. K., P. J. Kehoe, and F. E. Kydland (1992): "International Real Business Cycles," Journal of Political Economy 100: 745-775. 
[4] Backus, D. K., P. J. Kehoe, and F. E. Kydland (1994): "Dynamics of the Trade Balance and the Terms of Trade: The J Curve?" American Economic Review 84: 84-103.

[5] Baxter, M. (1995): "International Trade and Business Cycles," in G. M. Grossman and K. Rogoff (eds.), Handbook of International Economics, vol. 3, pp. 1801-1864, Amsterdam: Elsevier.

[6] Baxter, M., and D. D. Farr (2005): "Variable Capital Utilization and International Business Cycles," Journal of International Economics 65: 335-347.

[7] Bernard, A. B., J. Eaton, J. B. Jensen, and S. Kortum (2003): "Plants and Productivity in International Trade," American Economic Review 93: 1268-1290.

[8] Bernard, A. B., S. J. Redding, and P. K. Schott (2006): "Multi-Product Firms and Product Switching," NBER WP 12293.

[9] Bilbiie, F. O., F. Ghironi, and M. J. Melitz (2005): "Endogenous Entry, Product Variety, and Business Cycles," mimeo, Oxford University.

[10] Broda, C., and A. Burstein (2006): "Extensive Margins, Trade Growth and Terms of Trade," mimeo, University of Chicago.

[11] Broda, C., J. Greenfield, and D. E. Weinstein (2006): "From Groundnuts to Globalization: A Structural Estimate of Trade and Growth," NBER WP 12512.

[12] Broda, C., and D. E. Weinstein (2006a): “Globalization and the Gains from Variety," Quarterly Journal of Economics 121:541-585.

[13] Broda, C., and D. E. Weinstein (2006b): "Product Creation and Destruction: Evidence and Price Implications," mimeo, University of Chicago.

[14] Campbell, J. R. (1998): "Entry, Exit, Embodied Technology, and Business Cycles," Review of Economic Dynamics 1: 371-408.

[15] Chaney, T. (2006): "Distorted gravity: Heterogeneous Firms, Market Structure and the Geography of International Trade," mimeo, University of Chicago.

[16] Chatterjee, S., and R. Cooper (1993): "Entry and Exit, Product Variety and the Business Cycle," NBER WP 4562. 
[17] Corsetti, G., L. Dedola, and S. Leduc (2004): "International Risk-Sharing and the Transmission of Productivity Shocks," ECB WP 308.

[18] Debaere, P., and H. Lee (2004): “The Real-Side Determinants of Countries' Terms of Trade: A Panel Data Analysis," mimeo, University of Texas, Austin.

[19] Devereux, M. B., A. C. Head, and B. J. Lapham (1996a): "Aggregate Fluctuations with Increasing Returns to Specialization and Scale," Journal of Economic Dynamics and Control 20: $627-656$.

[20] Devereux, M. B., A. C. Head, and B. J. Lapham (1996b): "Monopolistic Competition, Increasing Returns, and the Effects of Government Spending," Journal of Money, Credit, and Banking 28: 233-254.

[21] Eaton, J., and S. Kortum (2002): "Technology, Geography, and Trade," Econometrica 70: 1741-79.

[22] Eaton, J., S. Kortum, and F. Kramarz (2004): “An Anatomy of International Trade: Evidence from French Firms," American Economic Review, P\&P 94:150-54.

[23] Feenstra, R. C., J. Romalis, and P. K. Schott (2002): "U.S. Imports, Exports, and Tariff Data, 1989-2001," NBER WP 9387.

[24] Ghironi, F. (2006): "Macroeconomic Interdependence under Incomplete Markets," Journal of International Economics 70: 428-450.

[25] Ghironi, F., and M. J. Melitz (2005): "International Trade and Macroeconomic Dynamics with Heterogeneous Firms," Quarterly Journal of Economics 120: 865-915.

[26] Helpman, E., M. J. Melitz, and Y. Rubinstein (2006), "Trading Partners and Trading Volumes," mimeo, Harvard University.

[27] Kehoe, P. J., and F. Perri (2002): "International Business Cycles with Endogenous Incomplete Markets," Econometrica 70: 907-928.

[28] Kehoe, T. J., and K. J. Ruhl (2002): "How Important Is the New Goods Margin in International Trade?" mimeo, University of Minnesota. 
[29] Obstfeld, M., and K. S. Rogoff (2001): "The Six Major Puzzles in International Macroeconomics: Is There a Common Cause?" in Bernanke, B. S., and K. S. Rogoff (eds.), NBER Macroeconomics Annual 2000, Cambridge: MIT Press, pp. 339-390.

[30] Ruhl, K. J. (2003): "Solving the Elasticity Puzzle in International Economics," mimeo, University of Minnesota.

[31] Schmitt-Grohé, S., and M. Uribe (2003): "Closing Small Open Economy Models," Journal of International Economics 61: 163-185.

[32] Uhlig, H. (1999): “A Toolkit for Analyzing Nonlinear Dynamic Stochastic Models Easily,” in Marimon, R., and A. Scott, eds., Computational Methods for the Study of Dynamic Economies, Oxford: Oxford University Press, pp. 30-61. 

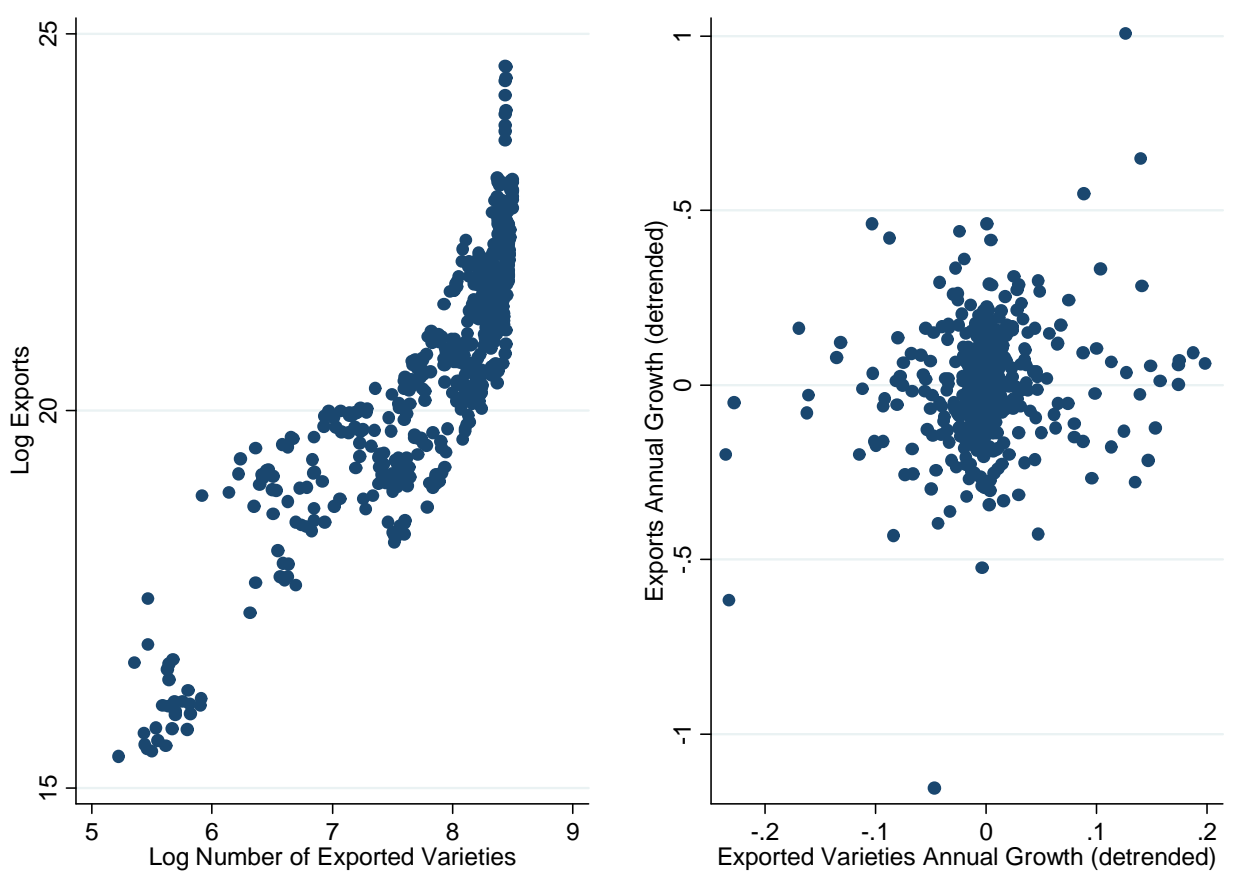

Figure 1: The Extensive Margin of Trade: Exports
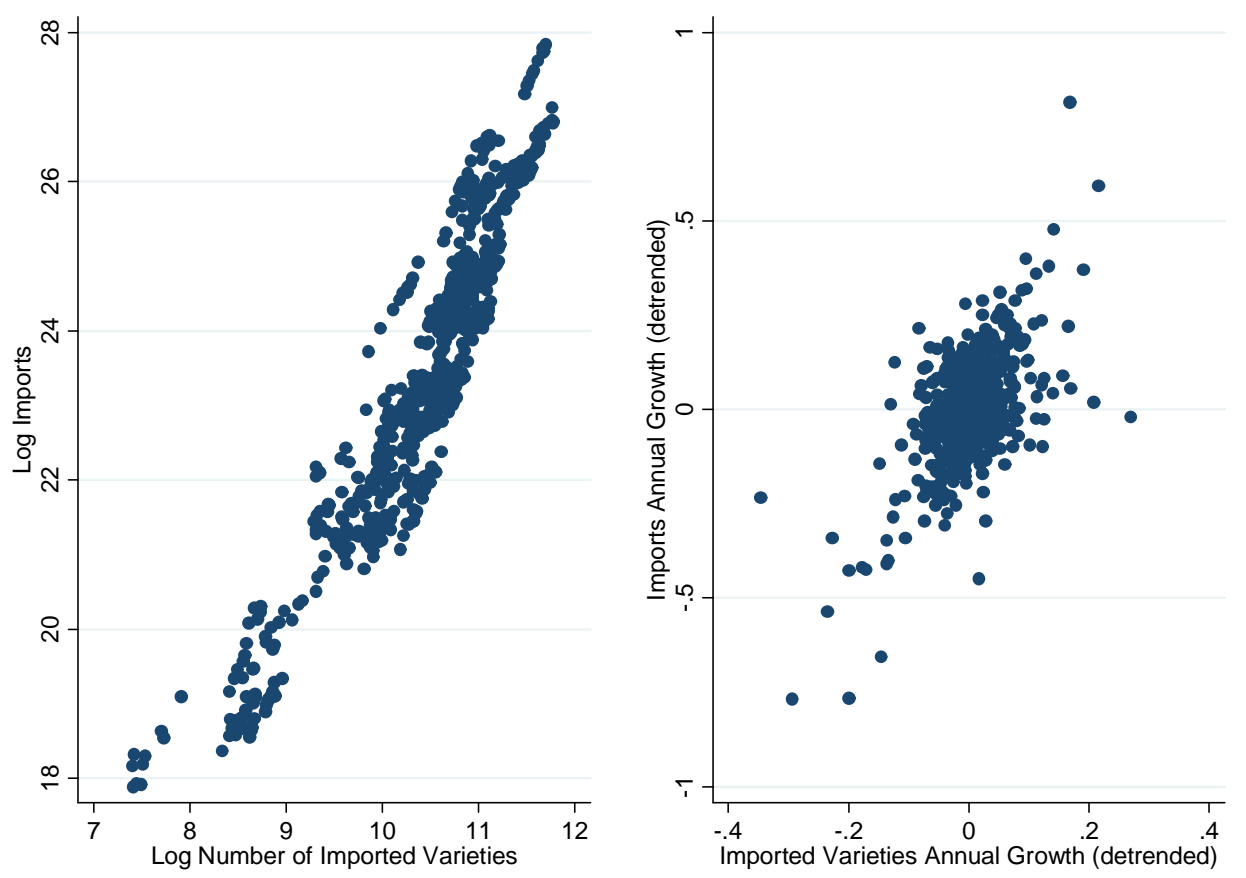

Figure 2: The Extensive Margin of Trade: Imports 

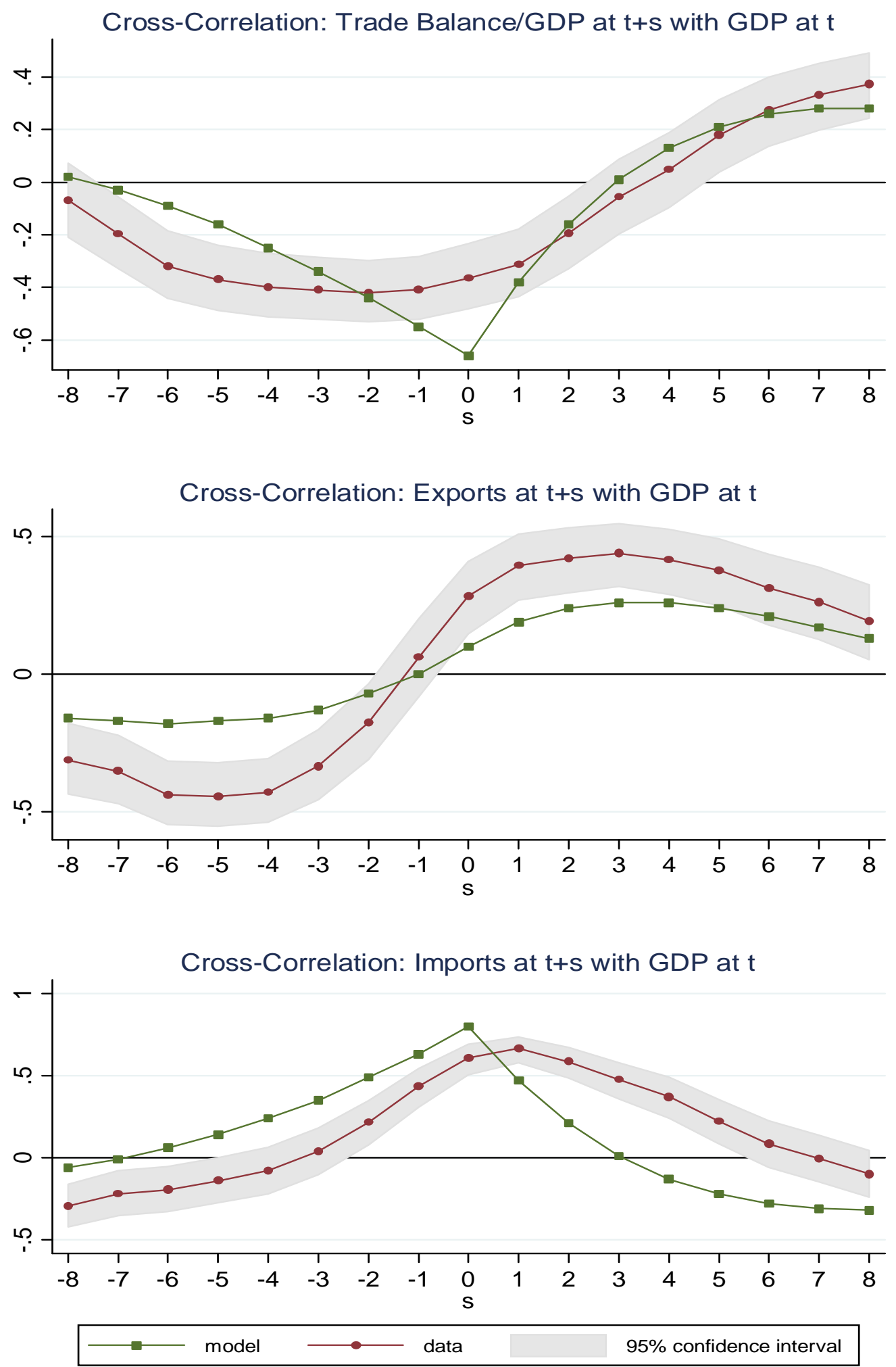

Figure 3: The Cyclicality of U.S. Trade 

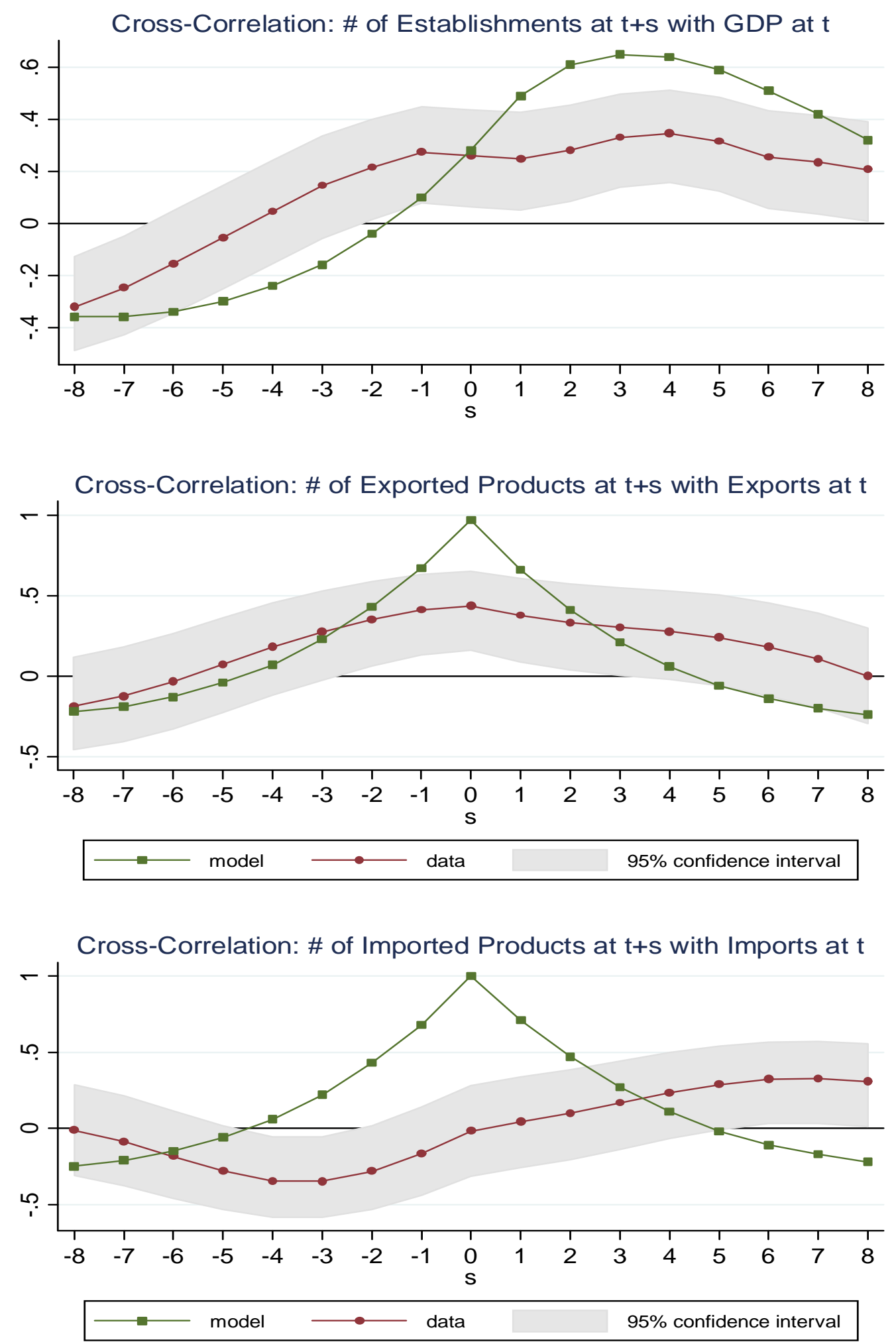

Figure 4: Domestic and Traded Variety 

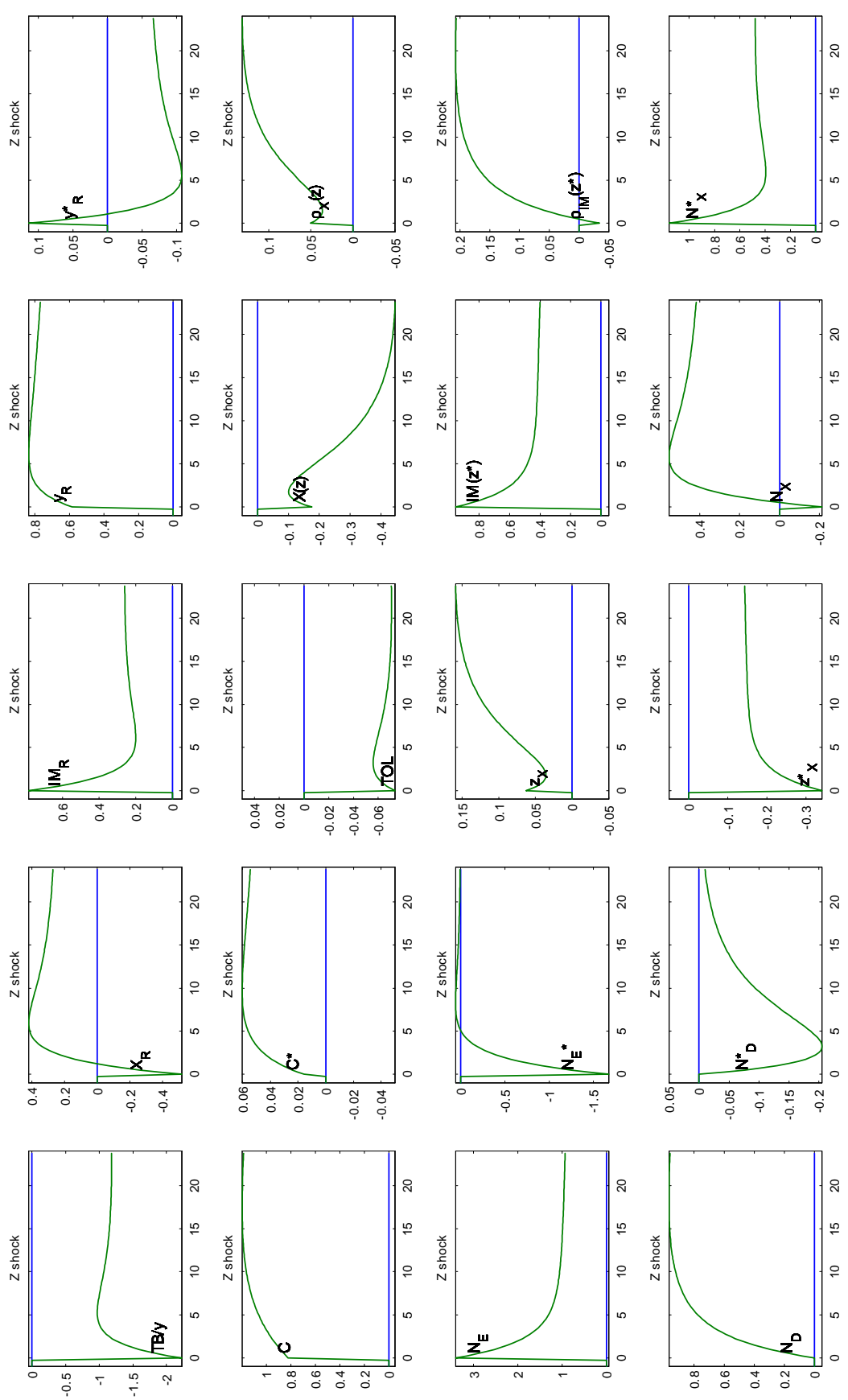

Figure 5: Impulse Responses 